Research Article

\title{
Determining the Height of Water-Flowing Fractured Zone in Bedrock-Soil Layer in a Jurassic Coalfield in Northern Shaanxi, China
}

\author{
Jie Feng $\mathbb{D}^{1,2}$ Sujian Wang $\mathbb{D}^{1,3}$ Enke Hou $\mathbb{D},{ }^{4}$ Xiang Ding, ${ }^{1}$ and Huijun Duan ${ }^{5}$ \\ ${ }^{1}$ China Coal Energy Research Institute Co., Ltd., Xi'an, Shaanxi, China \\ ${ }^{2}$ Innovation Team of "Mining Geology" for Sanqin Scholar, Xi'an, Shaanxi, China \\ ${ }^{3}$ Shaanxi Coal and Chemical Technology Institute Co., Ltd., Xi'an, Shaanxi, China \\ ${ }^{4}$ Department of Geology and Environment Engineering, Xi'an University of Science and Technology, Xi'an, Shaanxi, China \\ ${ }^{5}$ Xi'an Research Institute of China Coal Technology \& Engineering Group Corp, Xi'an, Shaanxi, China
}

Correspondence should be addressed to Jie Feng; fengjie0215@126.com and Sujian Wang; wangsj@sxccti.com

Received 19 April 2021; Accepted 27 September 2021; Published 21 October 2021

Academic Editor: Lishuai Jiang

Copyright ( $\odot 2021$ Jie Feng et al. This is an open access article distributed under the Creative Commons Attribution License, which permits unrestricted use, distribution, and reproduction in any medium, provided the original work is properly cited.

\begin{abstract}
The height of the water-flowing fractured zone is the most important technical parameter for water prevention and control in a coal mine. Due to the numerous factors affecting the water-flowing fractured zone, it is difficult to accurately identify the zone. Currently, no effective way exists for determination of the water-flowing fractured zone in a soil layer. To accurately determine the development law of the water-flowing fractured zone in the bedrock-soil layer of a Jurassic coalfield in northern Shaanxi, China, we conducted a comprehensive study using microresistivity scanning imaging technology, apparent density logging, long-range gamma logging, observation on drilling flushing fluid consumption, physical simulation, and numerical simulation. The following results were obtained: (1) The ratio of the height of the water-flowing fractured zone to the mining height was 28.3-28.5, which was obtained by microresistivity scanning imaging technology, whereas the ratio of the height of the water-flowing fractured zone to the mining height was 28.1-29.1, determined by apparent density logging, long-range gamma logging, physical simulation, and numerical simulation. The microresistivity scanning imaging results were consistent with those obtained by other methods. (2) Based on the thickness of the soil layer and the bedrock, the height model of the water-flowing fracture zone was divided into four regions, that is, the thick bedrock-thick soil layer region, thick bedrock-thin soil layer region, thin bedrock-thin soil layer region, and thin bedrock-thick soil layer region. A mathematical model describing the difference between the thickness of the waterflowing fractured zone and the bedrock and the thickness of the soil under the condition of bedrock-soil was established. (3) We conclude that microresistivity scanning imaging technology can accurately detect the height of the water-flowing fractured zone in a soil layer, and the apparent density logging and long-range gamma logging can precisely detect the height of the water-flowing fractured zone in bedrock. This is a new comprehensive method for research on the height of the water-flowing fractured zone that can provide a reliable basis for water prevention and control in mines.
\end{abstract}

\section{Introduction}

China ranks third in the world in terms of its reserve of coal resources. The Jurassic coalfield in northern Shaanxi is the seventh largest coalfield in China. Northern Shaanxi coal production base is one of the fourteen billion-ton coal production bases with high coal seam occurrence condition and excellent coal quality, which is planned and constructed in China. However, the ecological environment is fragile, because the aquifer Salawusu Formation aquifer is overlying the coal seam that is not only the chief water supply source in the region but also the main water source used to maintain the fragile ecological environment in the desert region [1-3]. The water-flowing fracture in coal seam mining is easy to communicate with this aquifer, resulting in mine water disaster accidents, leading 
to the decline of groundwater level and the degradation of supergene ecology.

It is very important to determine the height of the waterflowing fractured zone because it concerns the coordination and balance between coal mining, water resources protection, and mine safety. The theoretical analysis, empirical formulas, physical and numerical simulations, field measurement, and other methods have been used to research the water-flowing fracture and obtained a great deal of encouraging results. The "key layer theory" proposed by Qian et al. [4] is the most widely used theoretical analysis method for calculating the water-flowing fractured zone [5]. Mathematical statistics is predominantly used to study the development height of a water-flowing fractured zone and compare the applicability with construction, water body, railway and main roadway coal pillar retention, and coal pressure mining rules [6-8]. Wang et al. [9] and Zhao et al. $[10,11]$ determined the height of the water-flowing fractured zone by examining the relationship between the waterflowing fractured zone and the coal mining parameters, which has laid the foundation of water-retaining coal mining. Underground mine water injection leakage measuring method with overhead borehole, transient electromagnetic method, drilling TV, and numerical simulation were previously applied to investigate the height of the water-flowing fractured zone in the roof above that was fully mechanized one passing full seam mining face $[12,13]$. Yang and Teng [14] observed the borehole flushing fluid consumption and determined the maximum height of the water fractured zone by three boreholes of 6206 working face in Wangzhuang coal mine. Based on the physical simulation method, the law of the cracked zones in the overburden strata of the Western mining area was also revealed by Huang et al. [15-17] and Cao et al. [18]. In recent years, the microseismic monitoring technique has been increasingly applied to examine the heights of water-flowing fractured zones [19, 20].

However, due to the existence of a thick loess layer in the ecologically fragile area of northern Shaanxi, the following difficulties were faced in determining the height of the waterflowing fractured zone. First, theoretical analysis, empirical formula, physical simulation, numerical simulation, and other methods are used to obtain the height of the waterflowing fractured zone indirectly, but the accuracy is low. Second, the observation method of borehole flushing fluid consumption is widely used in field measurements. However, due to the water insulation effect of the flushing fluid mixed with loess and the insignificant change of the flushing fluid leakage, no accurate determination of the height of the water-flowing fractured zone is possible. Third, the detection of the drilling TV method has good applicability in field measurements in bedrock. In loess, since the water-flowing fracture is filled by loess itself during drilling, it is difficult to directly and clearly observe the fracture, and the height of the water-flowing fractured zone cannot be determined. Currently, the borehole flushing fluid consumption observation method is the most direct, accurate, and widely applied method for the development height of water-flowing fractured zone in the bedrock, but its disadvantage is its great time consumption. Another detection technology utilized to compare and verify the detection result obtained by the observation method of borehole flushing fluid consumption can increase the reliability of the final result. Therefore, in this paper, the microresistivity scanning imaging technology was employed to elucidate the development law of the waterflowing fracture in the soil layer of this area. The apparent density logging and long-range gamma logging are used to detect the development height of the water-flowing fracture zone in the bedrock. Auxiliary physical simulation and numerical simulation, as well as a comprehensive study of the water-flowing fractured zone, were carried out to fill the gaps in research on determining the height of the waterflowing fractured zone in the soil layer. The methods to identify the height of the water-flowing fractured zones in different types of bedrock-soil layers were extended, and the research results concerning the development law of waterflowing fractured zone were further improved.

\section{General Geological Parameters of the Study Area}

The northern Shaanxi coal production base lies in the semiarid areas at the border between the Maowusu Desert and the Loess Plateau and has an annual precipitation of approximately $400 \mathrm{~mm}$ and evaporation of approximately $2,000 \mathrm{~mm}$. In this study, we selected Zhangjiamao and Caojiatan coal mines as the research area (Figure 1). We investigated the height of the water-flowing fractured zone in the soil layer and in the bedrock.

The Zhangjiamao coal mine is dominated by loess of the Quaternary Middle Pleistocene Lishi Formation. The general thickness is $20-30 \mathrm{~m}$, whereas the maximum thickness is $90.5 \mathrm{~m}$. The loess lithology is silty clay with large porosity, loose structure, and a small amount of sandy soil in the area. Vertical joints are developed, which are easy to be eroded by surface water, and thus the immersion can easily lose stability. Under the influence of water erosion, gully development in loess area, and gully slope formation, collapse often occurs, resulting in a prevalence of gully head erosion. According to the soil test data, the loess void ratio is 0.818 , the plastic limit is $17.7 \%$, the liquid limit is $29.0 \%$, the natural water content is $5.3 \%$, and the liquid index is 0 . The soil is in a hard or hard-plastic state. The compression coefficient is within $0.04-1 \mathrm{MPa}^{-1}$, the compression modulus is $45.4 \mathrm{MPa}$, and the collapse coefficient is 0.010 with no collapsibility.

The overlying bedrock of Caojiatan coal mine consists mainly of Jurassic Yan'an Formation $\left(\mathrm{J}_{2} y\right)$ and Zhiluo Formation $\left(\mathrm{J}_{2} z\right)$ strata with a thickness of $164.33-294.48 \mathrm{~m}$. The rock mechanics test results showed that the saturated compressive strength of the direct roof of the coal seam is $24.80-37.90 \mathrm{MPa}$ with an average value of $31.35 \mathrm{MPa}$. The tensile strength is $0.39-0.56 \mathrm{MPa}$, with an average value of $0.48 \mathrm{MPa}$. The saturated compressive strength of the basic top is within the range of $27.60-37.90 \mathrm{MPa}$, with an average value of $33.25 \mathrm{MPa}$. The tensile strength is $0.23-1.14 \mathrm{MPa}$, with an average value of $0.71 \mathrm{MPa}$. The immediate roof and basic roof of the coal seam are medium-hard rocks that are easy to soften. 


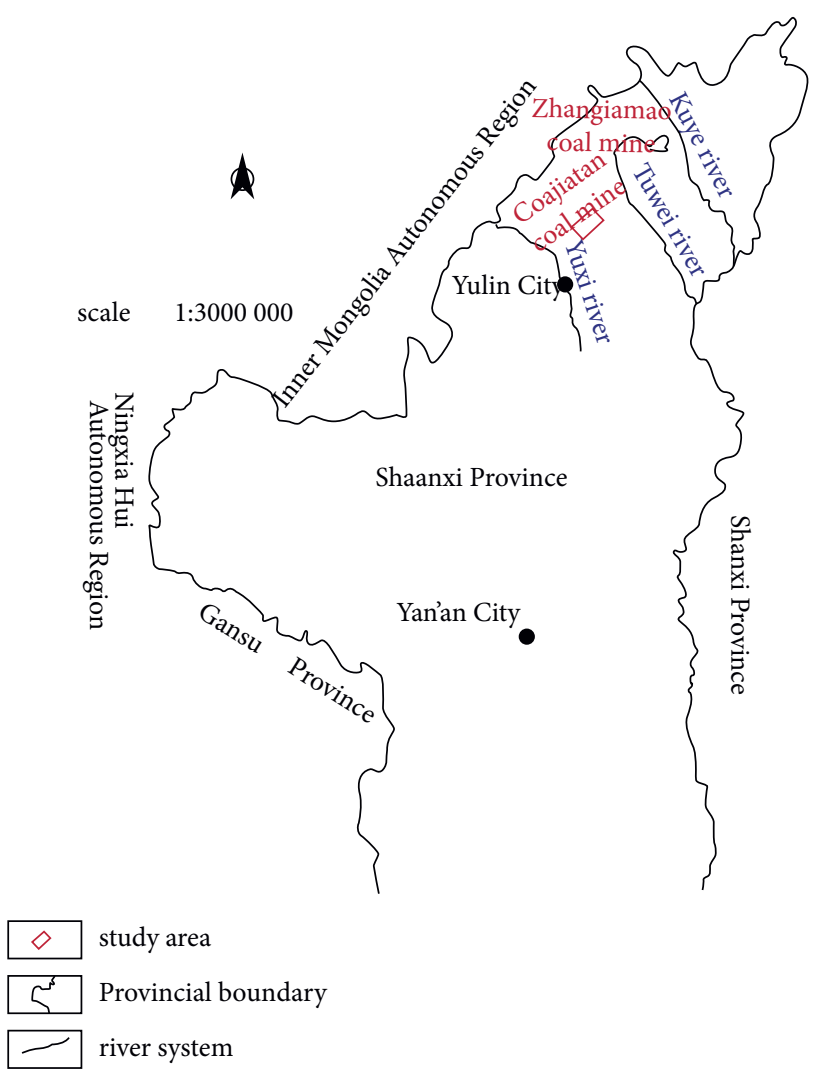

Figure 1: Map of the study area.

The relationship between the coal seam and the overlying bedrock and soil layer is illustrated in Figure 2.

\section{Determination of Water-Flowing Fractured Zone by Physical and Numerical Simulation}

3.1. Physical Simulation Study on the Height of the WaterFlowing Fractured Zone. Taking $5^{-2}$ coal seam mining in Zhangjiamao coal mine as an example, the 12-2 drilling columnar located in the drilling exploration area 9 of the water-flowing fractured zone was selected as the experimental prototype. Using a plane model frame, the length of the model was determined to be $3.0 \mathrm{~m}$ and the width was $0.2 \mathrm{~m}$ with a geometric similarity ratio of $1: 120$. The mining height of $5^{-2}$ coal seam was $4.88 \mathrm{~m}$, the overlying bedrock thickness was $96.12 \mathrm{~m}$, and the loess thickness was $48.16 \mathrm{~m}$. Table 1 represents the material matching scheme of the model.

The simulation test showed that the working face advanced to a total of $240 \mathrm{~m}$, and the initial weighting step was $36 \mathrm{~m}$, which can be observed in Figure 3(a). At the end of the working face mining, the height of the water-flowing fractured zone developed to the middle of the soil layer, and the height was roughly $137 \mathrm{~m}$. The ratio of the water-flowing fractured zone to the mining height was approximately 28.1 (Figure 3(b)).

Caojiatan coal mine uses the $2^{-2}$ coal seam. The D1 drilling columnar located in the area of the exploration drilling DZ1 of the water-flowing fractured zone was selected as the experimental prototype. Using a plane model frame, we determined the length of the model, which was $3.0 \mathrm{~m}$, and the width was $0.2 \mathrm{~m}$, with a geometric similarity ratio $1: 200$. The mining height of the $5^{-2}$ coal seam was $6 \mathrm{~m}$; the overlying bedrock thickness was $173.3 \mathrm{~m}$, and the loess thickness was $75.9 \mathrm{~m}$. Table 2 displays the material matching scheme of the model.

The simulation test revealed that the working face advanced $400 \mathrm{~m}$ in total, and the initial weighting step was $42 \mathrm{~m}$. At the end of the working face mining, the height of the water-flowing fractured zone developed to approximately $162 \mathrm{~m}$. The ratio of the water-flowing fractured zone to the mining height was about 27 and did not communicate with the soil layer (Figure 4).

3.2. Numerical Simulation Study on the Height of the WaterFlowing Fractured Zone. A numerical simulation model with a length of $500 \mathrm{~m}$ and a height of $191 \mathrm{~m}$ was established based on the drilling histogram of the area of the Zhangjiamao coal mine, where the N15203 working face 9 was located. A $100 \mathrm{~m}$ boundary coal pillar was set on both sides of the model. The mining height of $5^{-2}$ coal seam was $5.5 \mathrm{~m}$, the overlying bedrock thickness was $105 \mathrm{~m}$, and soil thickness was $60 \mathrm{~m}$. Table 3 lists the physical and mechanical properties of the rock coal seam overlying strata of the $5^{-2}$ coal seam of the model.

The simulation test results showed that the initial weighting step was $55 \mathrm{~m}$. After the overlying strata of $5^{-2}$ coal seam were stabilized, the height of the water-flowing fractured zone was approximately $160 \mathrm{~m}$, and the ratio of the water-flowing fractured zone to the mining height was $29.1 \mathrm{~m}$ (Figure 5).

A numerical simulation model with a length of $500 \mathrm{~m}$ and a height of $286 \mathrm{~m}$ was established according to the drilling histogram of the area, where 122106 working face D1 was located in Caojiatan coal mine. A $100 \mathrm{~m}$ boundary coal pillar was set on both sides of the model. The mining height of the $2^{-2}$ coal seam was $6 \mathrm{~m}$, the overlying bedrock thickness was $168 \mathrm{~m}$, and the soil thickness was $90 \mathrm{~m}$.

Table 4 shows the physical and mechanical properties of rock coal seam overlying strata of $2^{-2}$ coal seam for the model.

The simulation test showed that the initial weighting step was $90 \mathrm{~m}$. After the overlying strata of $2^{-2}$ coal seam were stabilized, the height of the water-flowing fractured zone was established to be roughly $162 \mathrm{~m}$, and the ratio of the waterflowing fractured zone to the mining height was $27 \mathrm{~m}$ (Figure 6).

\section{Apparent Density Logging and Long-Range Gamma Logging for Detection of the Height of the Water-flowing Fractured Zone in the Bedrock}

4.1. Detection Principles of Apparent Density Logging and Long-Range Gamma Logging. Rock fractures are developed by mining damage, reducing the density of the rock mass and the resistivity value. This method can explain the 


\begin{tabular}{|c|c|c|c|c|c|}
\hline \multicolumn{3}{|c|}{ stratigraphic age } & $\begin{array}{l}\text { thickness (m) } \\
\min \sim \max \end{array}$ & $\begin{array}{l}\text { lithological } \\
\text { description }\end{array}$ & $\begin{array}{l}\text { aquifer/ } \\
\text { aquifuge }\end{array}$ \\
\hline \multirow{3}{*}{ 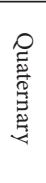 } & \multirow{2}{*}{\multicolumn{2}{|c|}{$\begin{array}{c}\text { Alluvial-pluvial } \\
\begin{array}{c}\text { Salawusu } \\
\text { formation }\end{array}\end{array}$}} & $0.9 \sim 60 / 10.49$ & \multirow{4}{*}{\begin{tabular}{|c|}
$\begin{array}{c}\text { mainly for modern } \\
\text { aeolian sand,sand and } \\
\text { sub-sand soil. }\end{array}$ \\
$\begin{array}{l}\text { gray yellow-brown black } \\
\text { silty sand, subsandy soil, } \\
\text { sandy clay. }\end{array}$ \\
$\begin{array}{c}\text { light brown-yellow } \\
\text { - brown subclay } \\
\text { sandy soil, silty sand, } \\
\text { paleosol, calcareous } \\
\text { nodule. }\end{array}$ \\
\end{tabular}} & \multirow{4}{*}{ aquifer } \\
\hline & & & $3 \sim 22.8 / 8.44$ & & \\
\hline & \multicolumn{2}{|c|}{ Lishi formation } & $4 \sim 88.74 / 27.12$ & & \\
\hline $\begin{array}{c}Z \\
8 \\
08 \\
08 \\
0 \\
0 \\
0\end{array}$ & \multicolumn{2}{|c|}{ Baode formation } & $1.7 \sim 77.35 / 27.4$ & & \\
\hline \multirow{15}{*}{ 㺼 } & \multicolumn{2}{|c|}{ Zhiluo formation } & 3.71 49.78/24.1 & \multirow{4}{*}{$\begin{array}{l}\text { brown-purpe red } \\
\text { clay or sandy } \\
\text { clay with } \\
\text { calcareous } \\
\text { nodules }\end{array}$} & \multirow{4}{*}{ aquifuge } \\
\hline & \multirow{14}{*}{$\begin{array}{l}\text { Yanan } \\
\text { forma- } \\
\text { tion }\end{array}$} & & $9.01 \sim 68.58 / 32.66$ & & \\
\hline & & $2^{-2}$ coal & $1.85 \sim 10.6 / 7.75$ & & \\
\hline & & & $23.68 \sim 38.7 / 30.42$ & & \\
\hline & & $3^{-1}$ coal & $2.1 \sim 3.4 / 2.81$ & \multirow{4}{*}{$\begin{array}{l}\text { purple mudstone, } \\
\text { sandy mudstone, } \\
\text { sandstone, sometimes } \\
\text { at the botton of the } \\
\text { conglomerate. }\end{array}$} & \multirow{4}{*}{ aquifer } \\
\hline & & & $37.96 \sim 47.36 / 42.1$ & & \\
\hline & & $4^{-2}$ coal & $1.25 \sim 4.75 / 3.63$ & & \\
\hline & & & $1.55 \sim 39.4 / 19.41$ & & \\
\hline & & $4^{-3}$ coal & $0.1 \sim 1.9 / 1.28$ & \multirow{7}{*}{$\begin{array}{l}\text { shallow gray-dark } \\
\text { gray sandstone and } \\
\text { mudstone, sandy } \\
\text { mudstone, containing } \\
\text { multi-layer coal seam, } \\
\text { is the main } \\
\text { coal-bearing strata of } \\
\text { the basin, up to } 13 \\
\text { layers of coal seam, } \\
\text { generally } 3 \sim 6 \text { layers. }\end{array}$} & \multirow{7}{*}{$\begin{array}{c}\text { aquifuge } \\
\text { combin- } \\
\text { ation }\end{array}$} \\
\hline & & & $2.56 \sim 35.65 / 14.57$ & & \\
\hline & & $4^{-4}$ coal & $0.1 \sim 1.2 / 0.79$ & & \\
\hline & & & $\begin{array}{c}28.95 \sim 79.23 \\
\quad / 35.74 \\
\end{array}$ & & \\
\hline & & $5^{-2}$ coal & $4.79 \sim 8.23 / 6.14$ & & \\
\hline & & & $0.41 \sim 21 / 2.47$ & & \\
\hline & & $5^{-3} \mathrm{coal}$ & $0.45 \sim 1.1 / 0.73$ & & \\
\hline
\end{tabular}

(a)

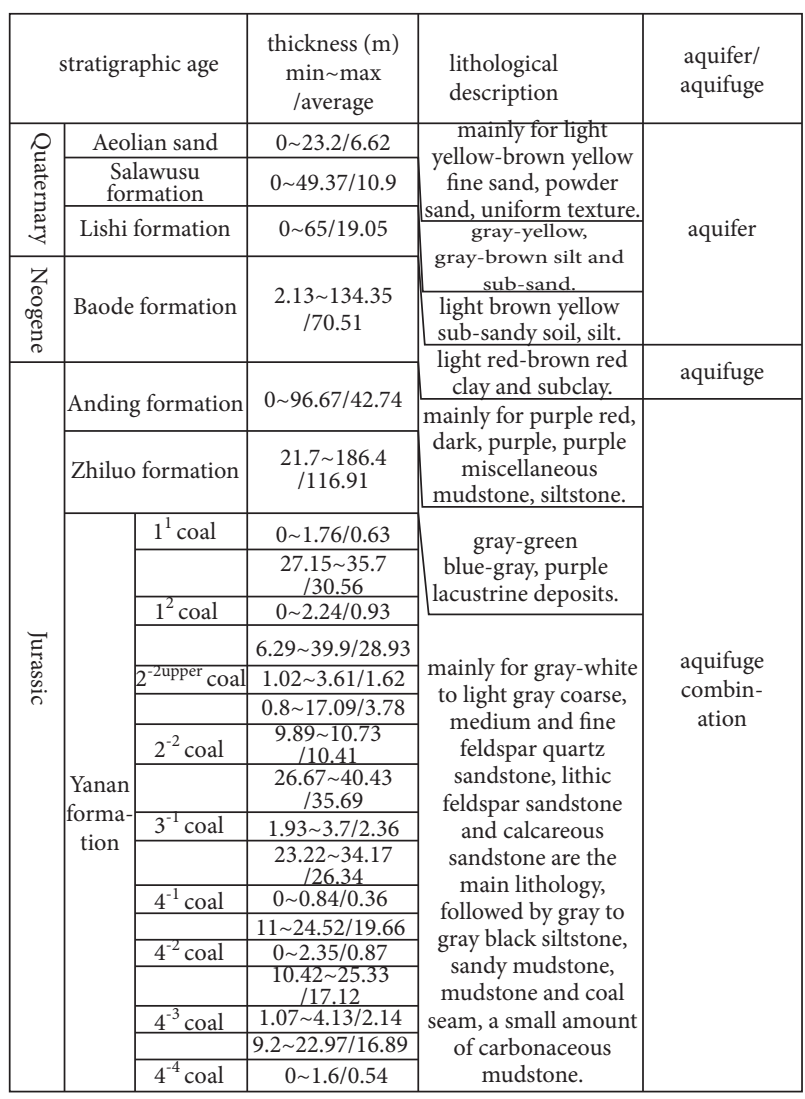

(b)

Figure 2: Relationship between the coal seam and the vertical distribution of the bedrock and the soil layer ((a) Zhangjiamao coal mine and (b) Caojiatan coal mine).

TABLE 1: Material matching scheme of the physical simulation model for $5^{-2}$ coal seam mining in Zhangjiamao coal mine.

\begin{tabular}{|c|c|c|c|c|c|c|c|c|}
\hline No. & Lithology & $\begin{array}{l}\text { Accumulated } \\
\text { thickness of the } \\
\text { original rock }(\mathrm{m})\end{array}$ & $\begin{array}{l}\text { Thickness of } \\
\text { the original } \\
\text { rock }(\mathrm{m})\end{array}$ & $\begin{array}{c}\text { Thickness } \\
\text { of } \backslash \text { the model } \\
(\mathrm{cm})\end{array}$ & $\begin{array}{l}\text { Accumulated } \\
\text { thickness of the } \\
\text { model }(\mathrm{cm})\end{array}$ & $\begin{array}{l}\text { Sand }(\mathrm{g} / \\
\mathrm{cm})\end{array}$ & $\begin{array}{l}\text { Gypsum } \\
(\mathrm{g} / \mathrm{cm})\end{array}$ & $\begin{array}{c}\text { Big white } \\
\text { powder }(\mathrm{g} / \mathrm{cm})\end{array}$ \\
\hline 19 & Loess & 48.16 & 48.16 & 40.13 & 124.90 & - & - & - \\
\hline 18 & $\begin{array}{l}\text { Medium grained } \\
\text { sandstone }\end{array}$ & 52.56 & 4.4 & 3.67 & 84.77 & 8640 & 288 & 672 \\
\hline 17 & $\begin{array}{l}\text { Fine grained } \\
\text { sandstone }\end{array}$ & 55.43 & 2.87 & 2.39 & 81.10 & 7680 & 384 & 1536 \\
\hline 16 & $\begin{array}{l}\text { Medium grained } \\
\text { sandstone }\end{array}$ & 56.7 & 1.27 & 1.06 & 78.71 & 8640 & 288 & 672 \\
\hline 15 & Siltstone & 65.96 & 9.26 & 7.72 & 77.65 & 7680 & 384 & 1536 \\
\hline 14 & $4^{-3}$ coal seam & 69.58 & 3.62 & 3.02 & 69.94 & - & - & - \\
\hline 13 & Siltstone & 71.2 & 1.62 & 1.35 & 66.92 & 7680 & 192 & 1728 \\
\hline 12 & Siltstone & 72.14 & 0.94 & 0.78 & 65.57 & 8640 & 288 & 672 \\
\hline 11 & $4^{-4}$ coal seam & 73.05 & 0.91 & 0.76 & 64.79 & - & - & - \\
\hline 10 & Siltstone & 75.4 & 2.35 & 1.96 & 64.03 & 8640 & 384 & 576 \\
\hline 9 & $\begin{array}{l}\text { Fine grained } \\
\text { sandstone }\end{array}$ & 82.8 & 7.4 & 6.17 & 62.07 & 7680 & 384 & 1536 \\
\hline 8 & Siltstone & 93.6 & 10.8 & 9.00 & 55.90 & 7680 & 576 & 1344 \\
\hline 7 & $\begin{array}{l}\text { Fine grained } \\
\text { sandstone }\end{array}$ & 96 & 2.4 & 2.00 & 46.90 & 8640 & 384 & 576 \\
\hline 6 & $\begin{array}{l}\text { Fine grained } \\
\text { sandstone }\end{array}$ & 104.8 & 8.8 & 7.33 & 44.90 & 7680 & 576 & 1344 \\
\hline 5 & Siltstone & 113.35 & 8.55 & 7.13 & 37.57 & 7680 & 384 & 1536 \\
\hline
\end{tabular}


TABLE 1: Continued.

\begin{tabular}{|c|c|c|c|c|c|c|c|c|}
\hline No. & Lithology & $\begin{array}{l}\text { Accumulated } \\
\text { thickness of the } \\
\text { original rock }(\mathrm{m})\end{array}$ & $\begin{array}{l}\text { Thickness of } \\
\text { the original } \\
\text { rock }(\mathrm{m})\end{array}$ & $\begin{array}{l}\text { Thickness } \\
\text { of \the model } \\
(\mathrm{cm})\end{array}$ & $\begin{array}{l}\text { Accumulated } \\
\text { thickness of the } \\
\text { model }(\mathrm{cm})\end{array}$ & $\begin{array}{l}\text { Sand }(\mathrm{g} / \\
\mathrm{cm})\end{array}$ & $\begin{array}{l}\text { Gypsum } \\
(\mathrm{g} / \mathrm{cm})\end{array}$ & $\begin{array}{c}\text { Big white } \\
\text { powder }(\mathrm{g} / \mathrm{cm})\end{array}$ \\
\hline 4 & Siltstone & 127.5 & 14.15 & 11.79 & 30.45 & 7680 & 576 & 1344 \\
\hline 3 & $\begin{array}{l}\text { Fine grained } \\
\text { sandstone }\end{array}$ & 129.6 & 2.1 & 1.75 & 18.65 & 7680 & 384 & 1536 \\
\hline 2 & Siltstone & 144.28 & 14.68 & 12.23 & 16.90 & 7680 & 576 & 1344 \\
\hline 1 & $5^{-2}$ coal seam & 149.88 & 5.6 & 4.67 & 4.67 & - & - & - \\
\hline
\end{tabular}

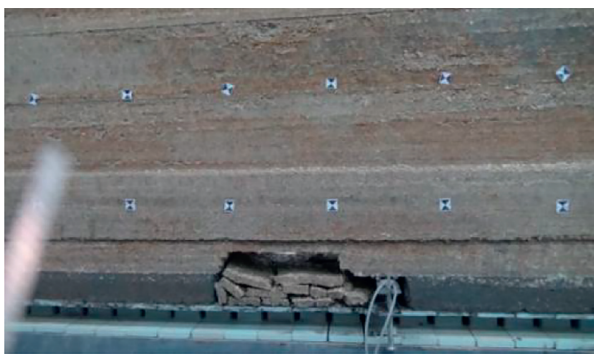

(a)

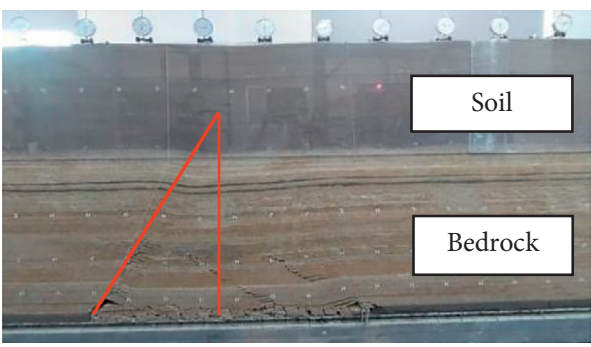

(b)

FIGURE 3: Characteristics of overburden failure after the extraction by physical simulation in the Zhangjiamao coal seam.

fracture development of the drilling wall, so as to determine the top interface position of the water-flowing fractured zone.
The apparent density is expressed as

$$
\text { apparent density }=\frac{\text { mass }}{\text { external actual volume }+ \text { internal closed pore volume }} \text {. }
$$

Note that the expression does not include the opening pore volume on the surface of the object.

Long-range gamma logging is a well-recognized logging method for geological engineering research, including stratigraphic lithology, mineral composition, density, porosity, and fluid migration. Its detection mechanism is based on the radiation field generated by natural or artificial gamma sources in formations and boreholes to measure and analyze the intensity and energy spectrum of the gamma line.

\subsection{Results of Apparent Density Logging and Long-Range} Gamma Logging for Water-Flowing Fractured Zone Detection. Two exploration drillings and one control drilling were performed in Caojiatan coal mine, denoted as DZ1, DZ2, and D1, respectively. They were located in 122106 goaf of the first working face (Figure 7 ). No. $2^{-2}$ coal seam with a mining thickness of $6 \mathrm{~m}$ was employed as the main mining coal seam. The bedrock thickness of DZ1 drilling was $175 \mathrm{~m}$; of DZ2 drilling, it was $178.9 \mathrm{~m}$. The working face was mined out. After the full mining of the coal seam, the water-flowing fractures in the overlying strata of the coal seam were detected.
From Figure 8, the following can be seen: (a) The apparent density of DZ1 drilling suddenly decreases at a depth of $131.39 \mathrm{~m}$ compared with that of D1 drilling, and there is a large sword-front anomaly in each interval below the depth of $131.39 \mathrm{~m}$, indicating that there is a gap in the drilling wall leading to a sudden decrease in the apparent density. The apparent density of DZ2 drilling suddenly becomes smaller than that of D1 drilling at a depth of $144.65 \mathrm{~m}$, with a sharp sword-like anomaly at each interval below a depth of $144.65 \mathrm{~m}$, indicating the presence of a gap in the hole wall, leading to the sudden decrease of the apparent density. (b) The long-range gamma of DZ1 drilling suddenly becomes larger than that of D1 drilling at a depth of $130.19 \mathrm{~m}$, and there is a sword-front anomaly in each interval below the depth of $130.19 \mathrm{~m}$, indicating that there is a gap in the drilling wall, resulting in the sudden enlargement of the long-range gamma. Compared with drilling D1, the long-range gamma of DZ2 drilling suddenly becomes larger at a depth of $145.54 \mathrm{~m}$, and there is a sword-front anomaly in each interval below the depth of $145.54 \mathrm{~m}$, indicating that there is a gap in the borehole wall, which leads to the sudden enlargement of the long-range gamma. 
TABLE 2: Material matching scheme of the physical simulation model of the $2^{-2}$ coal seam mining in Caojiatan coal mine.

\begin{tabular}{|c|c|c|c|c|c|c|c|c|}
\hline No. & Lithology & $\begin{array}{l}\text { The thickness of } \\
\text { the original rock } \\
\text { (m) }\end{array}$ & $\begin{array}{l}\text { The accumulated } \\
\text { thickness of the } \\
\text { original rock (m) }\end{array}$ & $\begin{array}{l}\text { The } \\
\text { thickness } \\
\text { of the model } \\
(\mathrm{cm})\end{array}$ & $\begin{array}{l}\text { The accumulated } \\
\text { thickness } \\
\text { of the model }(\mathrm{cm})\end{array}$ & $\begin{array}{l}\text { Sand } \\
(\mathrm{g} / \mathrm{cm})\end{array}$ & $\begin{array}{c}\text { Gypsum } \\
(\mathrm{g} / \mathrm{cm})\end{array}$ & $\begin{array}{l}\text { The big white } \\
\text { powder }(\mathrm{g} / \mathrm{cm})\end{array}$ \\
\hline 1 & $2^{-2}$ coal seam & 12.0 & 10.0 & 5.0 & 5.0 & - & - & - \\
\hline 2 & Siltstone & 2.0 & 12.0 & 1.0 & 6.0 & 8640 & 288 & 672 \\
\hline 3 & $\begin{array}{l}\text { Fine grained } \\
\text { sandstone }\end{array}$ & 14.0 & 26.0 & 7.0 & 13.0 & 7680 & 576 & 1344 \\
\hline 4 & $\begin{array}{l}\text { Coarse grained } \\
\text { sandstone }\end{array}$ & 18.0 & 44.0 & 9.0 & 22.0 & 7680 & 384 & 1536 \\
\hline 5 & $\begin{array}{l}\text { Medium } \\
\text { grained } \\
\text { sandstone }\end{array}$ & 6.0 & 50.0 & 3.0 & 25.0 & 7680 & 768 & 1152 \\
\hline 6 & Siltstone & 22.0 & 72.0 & 11.0 & 36.0 & 8640 & 288 & 672 \\
\hline 7 & $\begin{array}{l}\text { Coarse grained } \\
\text { sandstone }\end{array}$ & 22.0 & 94.0 & 11.0 & 47.0 & 7680 & 384 & 1536 \\
\hline 8 & $\begin{array}{l}\text { Medium } \\
\text { grained } \\
\text { sandstone }\end{array}$ & 10.0 & 104.0 & 5.0 & 52.0 & 7680 & 768 & 1152 \\
\hline 9 & $\begin{array}{l}\text { Coarse grained } \\
\text { sandstone }\end{array}$ & 14.0 & 118.0 & 7.0 & 59.0 & 7680 & 384 & 1536 \\
\hline 10 & Siltstone & 2.0 & 120.0 & 1.0 & 60.0 & 8640 & 288 & 672 \\
\hline 11 & $\begin{array}{l}\text { Fine grained } \\
\text { sandstone }\end{array}$ & 6.0 & 126.0 & 3.0 & 63.0 & 7680 & 576 & 1344 \\
\hline 12 & Siltstone & 6.0 & 132.0 & 3.0 & 66.0 & 8640 & 288 & 672 \\
\hline 13 & $\begin{array}{l}\text { Fine grained } \\
\text { sandstone }\end{array}$ & 2.0 & 134.0 & 1.0 & 67.0 & 7680 & 576 & 1344 \\
\hline 14 & Siltstone & 4.0 & 138.0 & 2.0 & 69.0 & 8640 & 288 & 672 \\
\hline 15 & $\begin{array}{l}\text { Sandy } \\
\text { mudstone }\end{array}$ & 2.0 & 140.0 & 1.0 & 70.0 & 8640 & 192 & 768 \\
\hline 16 & Siltstone & 2.0 & 142.0 & 1.0 & 71.0 & 8640 & 288 & 672 \\
\hline 17 & $\begin{array}{l}\text { Medium } \\
\text { grained } \\
\text { sandstone }\end{array}$ & 6.0 & 148.0 & 3.0 & 74.0 & 7680 & 768 & 1152 \\
\hline 18 & $\begin{array}{l}\text { Fine grained } \\
\text { sandstone }\end{array}$ & 4.0 & 152.0 & 2.0 & 76.0 & 7680 & 576 & 1344 \\
\hline 19 & Siltstone & 14.0 & 166.0 & 7.0 & 83.0 & 8640 & 288 & 672 \\
\hline 20 & $\begin{array}{l}\text { Sandy } \\
\text { mudstone }\end{array}$ & 4.0 & 170.0 & 2.0 & 85.0 & 8640 & 192 & 768 \\
\hline 21 & $\begin{array}{l}\text { Medium } \\
\text { grained } \\
\text { sandstone }\end{array}$ & 2.0 & 172.0 & 1.0 & 86.0 & 7680 & 768 & 1152 \\
\hline 22 & $\begin{array}{l}\text { Fine grained } \\
\text { sandstone }\end{array}$ & 2.0 & 174.0 & 1.0 & 87.0 & 7680 & 576 & 1344 \\
\hline 23 & Siltstone & 6.0 & 180.0 & 3.0 & 90.0 & 8640 & 288 & 672 \\
\hline 24 & $\begin{array}{l}\text { Medium } \\
\text { grained } \\
\text { sandstone }\end{array}$ & 4.0 & 184.0 & 2.0 & 92.0 & 7680 & 768 & 1152 \\
\hline 25 & $\begin{array}{l}\text { Fine grained } \\
\text { sandstone }\end{array}$ & 2.0 & 186.0 & 1.0 & 93.0 & 7680 & 576 & 1344 \\
\hline 26 & Laterite & 36.0 & 222.0 & 18.0 & 111.0 & 8640 & 96 & 864 \\
\hline 27 & Loess & 40.0 & 262.0 & 20.0 & 131.0 & 8640 & 96 & 864 \\
\hline 28 & Drift sand & 18.0 & 280.0 & 9.0 & 140.0 & 8640 & 96 & 864 \\
\hline
\end{tabular}

According to the aforementioned characteristics, the top boundary position of the water-flowing fractured zone for DZ1 drilling is $130.19 \mathrm{~m}$, and the top boundary position of the water-flowing fractured zone for DZ2 drilling is $144.65 \mathrm{~m}$. The depth of $2^{-2}$ coal in DZ1 drilling and DZ2 drilling is $269.8 \mathrm{~m}$ and $273.4 \mathrm{~m}$, respectively. Then, the height 


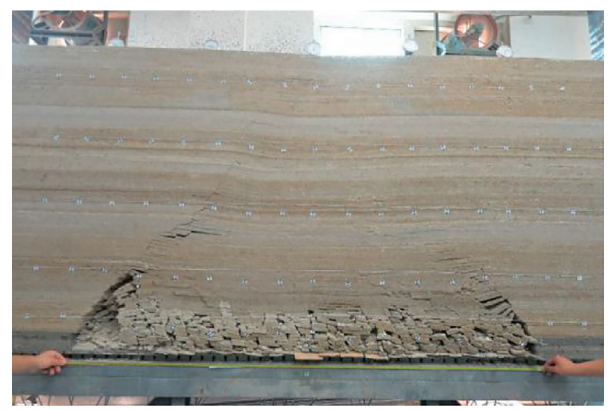

FIGURE 4: Characteristics of overburden failure after the extraction by physical simulation in Caojiatan coal seam.

TABLE 3: Physical and mechanical properties of the rock coal seam overlying the strata of the $5^{-2}$ coal seam in Zhangjiamao coal seam.

\begin{tabular}{|c|c|c|c|c|c|c|c|c|c|}
\hline No. & Lithology & $\begin{array}{l}\text { The } \\
\text { thickness } \\
\text { (m) }\end{array}$ & $\begin{array}{l}\text { The buried } \\
\text { depth }(\mathrm{m})\end{array}$ & $\begin{array}{c}\text { The } \\
\text { density } \\
\left(\mathrm{g} / \mathrm{cm}^{3}\right)\end{array}$ & $\begin{array}{l}\text { Uniaxial } \\
\text { compressive } \\
\text { strength } \\
(\mathrm{MPa})\end{array}$ & $\begin{array}{l}\text { Modulus of } \\
\text { elasticity } \\
(\mathrm{MPa})\end{array}$ & $\begin{array}{c}\text { Tensile } \\
\text { strength } \\
(\mathrm{MPa})\end{array}$ & $\begin{array}{l}\text { Cohesion } \\
\text { (MPa) }\end{array}$ & $\begin{array}{c}\text { Angle of } \\
\text { internal friction }\left({ }^{\circ}\right)\end{array}$ \\
\hline 1 & Loess & 60 & 60 & 1620 & 700 & 600 & 0.2 & 0.32 & 20 \\
\hline 2 & $\begin{array}{l}\text { Fine grained } \\
\text { sandstone }\end{array}$ & 10 & 70 & 2600 & 4500 & 3800 & 1.2 & 1.8 & 20 \\
\hline 3 & $\begin{array}{c}\text { Sandy } \\
\text { mudstone }\end{array}$ & 6 & 76 & 2400 & 4000 & 3200 & 1.2 & 1.6 & 25 \\
\hline 4 & $\begin{array}{l}\text { Siltstone } \\
\text { Medium }\end{array}$ & 4 & 80 & 2400 & 4500 & 3800 & 1.2 & 1.8 & 20 \\
\hline 5 & $\begin{array}{c}\text { grained } \\
\text { sandstone }\end{array}$ & 6 & 86 & 2400 & 4000 & 3200 & 1.2 & 1.6 & 25 \\
\hline 6 & $\begin{array}{l}\text { Fine grained } \\
\text { sandstone }\end{array}$ & 5 & 91 & 2600 & 4500 & 3800 & 1.2 & 1.8 & 20 \\
\hline 7 & $\begin{array}{l}\text { Medium } \\
\text { grained } \\
\text { sandstone }\end{array}$ & 12 & 103 & 2520 & 4000 & 3200 & 1.2 & 1.6 & 25 \\
\hline 8 & $\begin{array}{l}\text { Fine grained } \\
\text { sandstone }\end{array}$ & 10 & 113 & 2600 & 6000 & 4800 & 1.5 & 1.9 & 34 \\
\hline 9 & Siltstone & 16 & 129 & 2400 & 4000 & 3200 & 1.2 & 1.6 & 25 \\
\hline 10 & $\begin{array}{l}\text { Fine grained } \\
\text { sandstone }\end{array}$ & 12 & 141 & 2600 & 5600 & 4200 & 1.5 & 1.9 & 28 \\
\hline 11 & $\begin{array}{l}\text { Siltstone } \\
\text { Medium }\end{array}$ & 18 & 159 & 2400 & 4500 & 3800 & 1.2 & 1.8 & 20 \\
\hline 12 & $\begin{array}{l}\text { grained } \\
\text { sandstone }\end{array}$ & 6 & 165 & 2520 & 4000 & 3200 & 1.2 & 1.6 & 25 \\
\hline 13 & $2^{-2}$ coal seam & 5.5 & 170.5 & 1420 & 2000 & 1800 & 1.0 & 1.0 & 15 \\
\hline 14 & $\begin{array}{l}\text { Fine grained } \\
\text { sandstone }\end{array}$ & 20.5 & 191 & 2600 & 5600 & 4200 & 1.5 & 1.9 & 28 \\
\hline
\end{tabular}

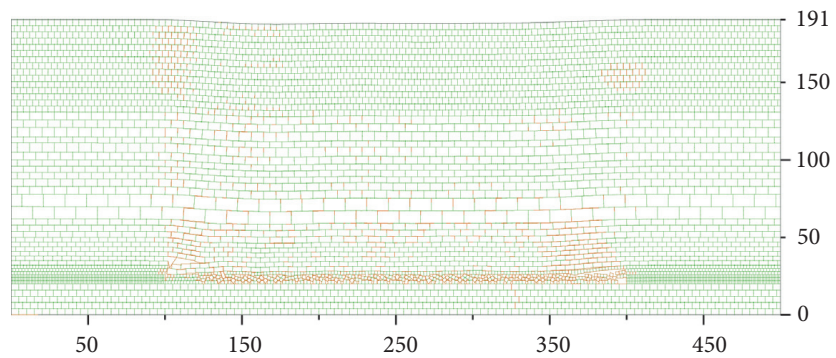

Figure 5: Characteristics of the overburden failure after the extraction by numerical simulation in Zhangjiamao coal mine (measurement unit: $\mathrm{m})$. 
TABLE 4: Physical and mechanical properties of rock coal seam overlying strata of coal seam in Caojiatan coal mine.

\begin{tabular}{|c|c|c|c|c|c|c|c|c|}
\hline No. & Lithology & $\begin{array}{l}\text { Thickness } \\
(\mathrm{m})\end{array}$ & $\begin{array}{c}\text { Buried } \\
\text { depth }(\mathrm{m})\end{array}$ & $\begin{array}{c}\text { Bulk modulus } \\
(\mathrm{MPa})\end{array}$ & $\begin{array}{c}\text { Shear modulus } \\
(\mathrm{MPa})\end{array}$ & $\begin{array}{c}\text { Angle of internal } \\
\text { friction }\left({ }^{\circ}\right)\end{array}$ & $\begin{array}{c}\text { Adhesion stress } \\
(\mathrm{MPa})\end{array}$ & $\begin{array}{c}\text { Tensile } \\
\text { strength }(\mathrm{MPa})\end{array}$ \\
\hline 1 & Loess & 90 & 1900 & - & - & - & - & - \\
\hline 2 & Sandy mudstone & 5 & 2570 & 3380 & 3150 & 39 & 5.6 & 5.9 \\
\hline 3 & $\begin{array}{l}\text { Medium grained } \\
\text { sandstone }\end{array}$ & 10 & 2670 & 3830 & 3750 & 40 & 6.7 & 6.3 \\
\hline 4 & $\begin{array}{l}\text { Fine grained } \\
\text { sandstone }\end{array}$ & 24 & 2700 & 3300 & 3160 & 32 & 6.5 & 6.8 \\
\hline 5 & Siltstone & 15 & 2500 & 3600 & 3670 & 24 & 6.8 & 6.7 \\
\hline 6 & $\begin{array}{l}\text { Medium grained } \\
\text { sandstone }\end{array}$ & 40 & 2100 & 3380 & 3150 & 20 & 5.6 & 6.8 \\
\hline 7 & $\begin{array}{l}\text { Fine grained } \\
\text { sandstone }\end{array}$ & 16 & 2600 & 3300 & 3160 & 27 & 6.5 & 6.7 \\
\hline 8 & $\begin{array}{l}\text { Medium grained } \\
\text { sandstone }\end{array}$ & 20 & 2500 & 3740 & 3570 & 24 & 6.3 & 6.8 \\
\hline 9 & $\begin{array}{l}\text { Fine grained } \\
\text { sandstone }\end{array}$ & 32 & 2400 & 3600 & 3660 & 20 & 6.3 & 6.8 \\
\hline 10 & Siltstone & 6 & 2500 & 3720 & 4630 & 24 & 8.6 & 5.7 \\
\hline 11 & $2^{-2}$ coal seam & 12 & 1400 & 1480 & 1480 & 17 & 2.5 & 3.8 \\
\hline 12 & Siltstone & 16 & 2500 & 3920 & 3700 & 23 & 8.5 & 5.5 \\
\hline
\end{tabular}

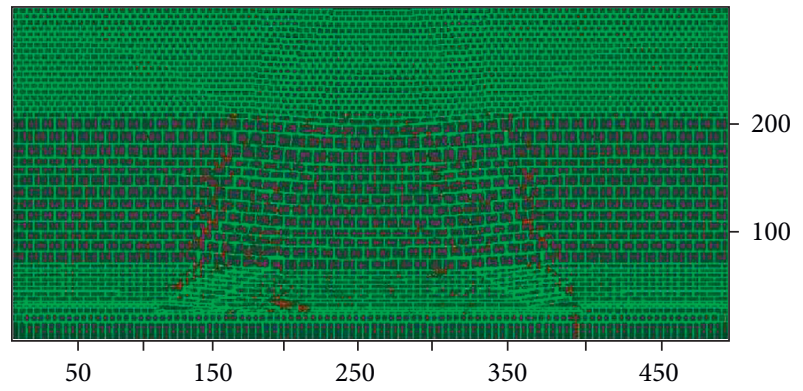

Figure 6: Characteristics of the overburden failure after the extraction by numerical simulation in Caojiatan coal mine (measurement unit: $\mathrm{m}$ ).

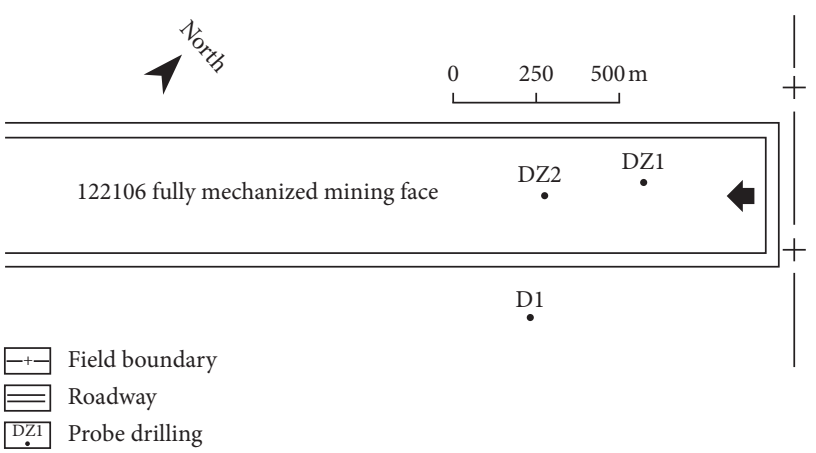

FIGURE 7: Layout of the detection drilling in the water-flowing fractured zone of Caojiatan coal mine.

of the water-flowing fractured zone in DZ1 and DZ2 drilling is $139.61 \mathrm{~m}$ and 128.75 , correspondingly. The ratio of the water-flowing fractured zone to mining height is 23.27 and 21.46, respectively.

\section{Microresistivity Scanning for Detection of the Height of Water-Flowing Fractured Zone in the Soil Layer}

5.1. Detection Principle of Microresistivity Scanning Imaging Technology. Microresistivity scanning imaging is an important drilling wall imaging method, which uses small electrodes like multirow of buttons a multipolar plate to emit current to a borehole wall stratum. When a difference exists in the rock composition, structure, and fluid contained at the electrode contact place, a change in the current occurs. This current change reflects the alteration of the rock resistivity around the drilling wall, which can display the resistivity imaging of the drilling wall.

A drilling wall microresistivity scanning imaging logging tool (MCI) is used to detect fractures in the soil layer [21-23]. An alternating current is emitted by the polar plate body of the thruster so that the current is returned to the loop electrode of the upper part of the instrument through the loop composed of the mud column and the formation in the well. The equipotential of the thruster and the metal connection of the plate focus the current flowing from the array button in the middle of the plate perpendicular to the outer surface of the plate into the formation. The measured array spike current intensity reflects the change in the microresistivity caused by rock structure or electrochemical heterogeneity in the stratigraphic field, where the spike is opposite (Figure 9).

5.2. Microresistivity Scanning Imaging Exploration. Two detection drillings, drilling 8 and drilling 9, were constructed in Zhangjiamao coal mine, which were located in the goaf of N15203 working face in the northern wing panel of Zhangiiamao coal mine (Figures 10 and 11). This was the 


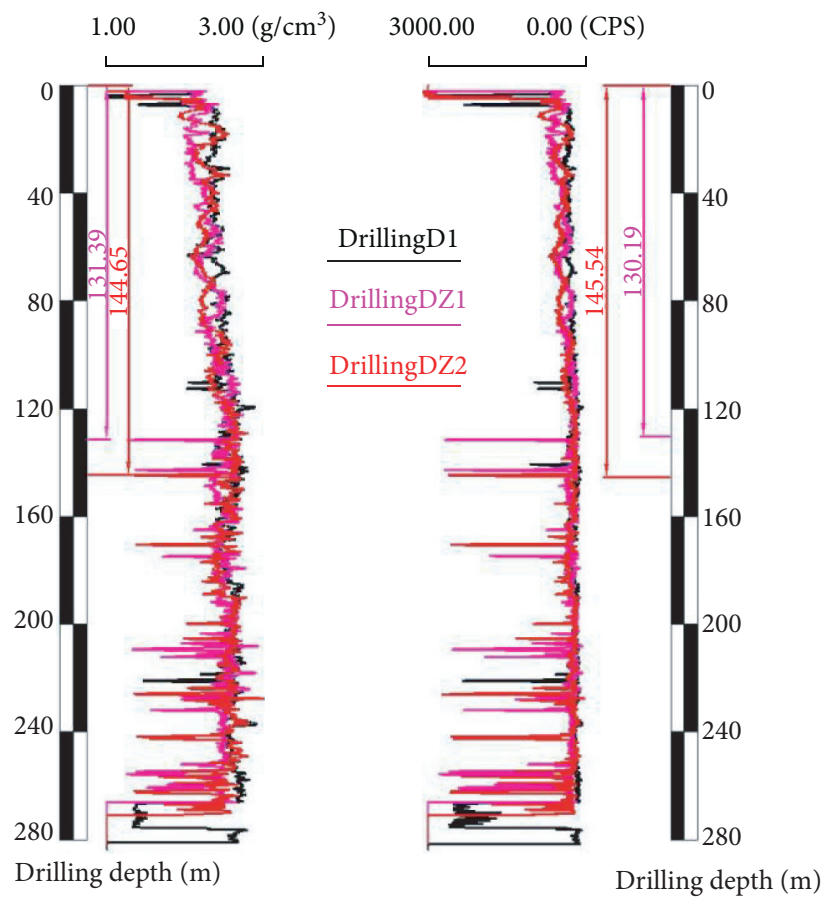

(a)

(b)

Figure 8: Apparent density logging and long-range gamma logging curve. (a) Apparent density. (b) Long-range gamma.

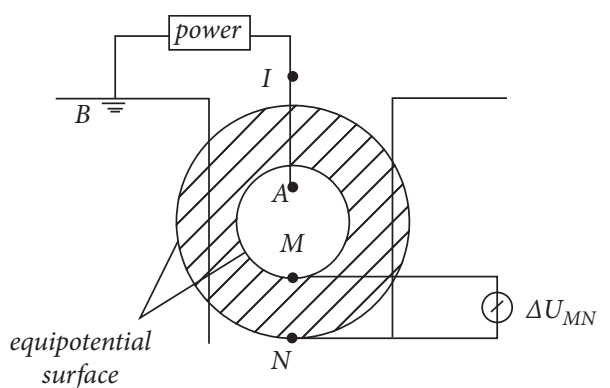

(a)

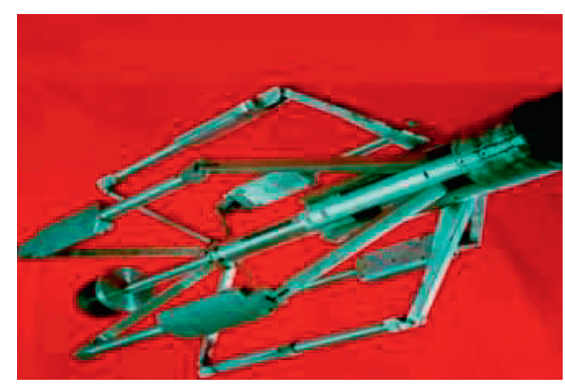

(b)

FIgURE 9: Microresistivity scanning imaging. (a) Measurement scheme. (b) Scanner plate morphology.

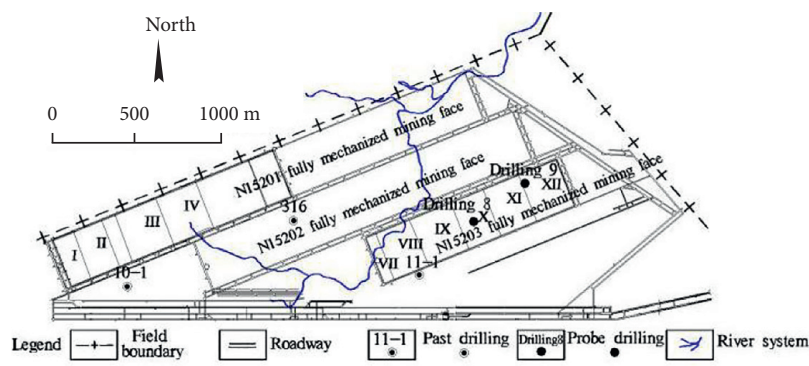

FIGURE 10: Layout drawing of exploration drilling with microresistivity scanning imaging in Zhangjiamao coal mine.

location of drilling 9 area exploration of the water-flowing fractured zone. No. $5^{-2}$ coal seam, with a mining thickness of $4.5 \mathrm{~m}$ and a buried depth of $149 \mathrm{~m}$, was used as the main mining coal seam. The soil thicknesses of drilling 8 and drilling 9 were, respectively, 21.92 and $58.89 \mathrm{~m}$. The working face was mined. After the full mining of the coal seam, the water-flowing fractures in the soil layer of approximately $100 \mathrm{~m}$ above the coal seam were detected. 


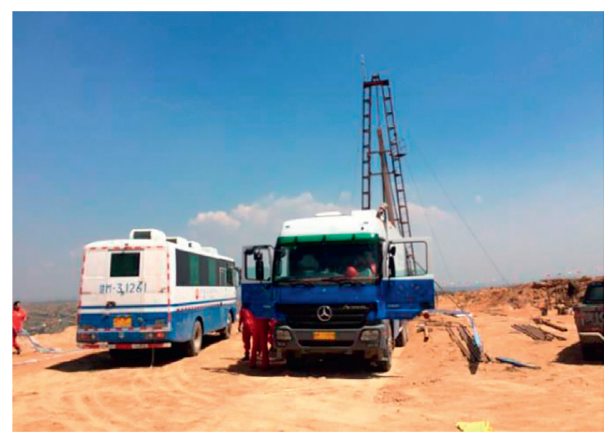

FIGURE 11: Construction site of the microresistivity scanning imaging in Zhangjiamao coal mine.

The measurement section of drilling 8 was $7.5-33.0 \mathrm{~m}$, and two water-flowing fractures were detected, of which two complete high-angle fractures were developed in the range 21.8-29.9 $\mathrm{m}$ (Figure 12). The simple hydrological observation results (Table 5) of the drilling showed that there was no water level total pump loss; it was observed to enter the water-flowing fractured zone. Based on this result, the ratio of the water-flowing fractured zone to the mining height was calculated to be 28.5. The main related characteristics are presented in Table 6.

The measurement section of drilling 8 was $7.5-33.0 \mathrm{~m}$, and two water-flowing fractures were detected, of which two complete high-angle fractures were developed in the range of 21.8-29.9 m (Figure 12). The simple hydrological observation results (Table 5) of the drilling showed that there was no water level total pump loss; it was observed to enter the water-flowing fractured zone. Based on this result, the ratio of the water-flowing fractured zone to the mining height was calculated to be 28.5 . The main related characteristics are presented in Table 6.

The measurement section of drilling 9 was 7-46 m. Here, four water-flowing fractures were detected, of which the complete high-angle fractures were developed in the range of 7.8-18.4 m (Figure 13). Our comparison between the results obtained by microresistivity scanning imaging and simple hydrology observation of soil layer (Table 5) revealed that the water level decreases rapidly from the depth of $18.4 \mathrm{~m}$, and the total pump leakage was gradually lost. The depth of $22.4 \mathrm{~m}$ enters the water-flowing fractured zone; the ratio of the water-flowing fractured zone to the mining height was 28.3. The data are shown in Table 7 .

5.3. Comparative Analysis of Microresistivity Scanning Imaging and Other Methods. Microresistivity scanning imaging technique detected water-flowing fractures in the soil layer at a depth of 7.8-21.8 m. Comprehensive borehole flushing fluid consumption indicated that the ratio of the water-flowing fractured zone to the mining height was 28.3-28.5. The water-conducting fractures obtained by physical simulation and numerical simulation were all developed to the soil layer, and the ratio of the waterflowing fractured zone to the mining height was within 27-29.1. According to the ratio of the water-flowing fractured zone, the physical simulation surface fracture

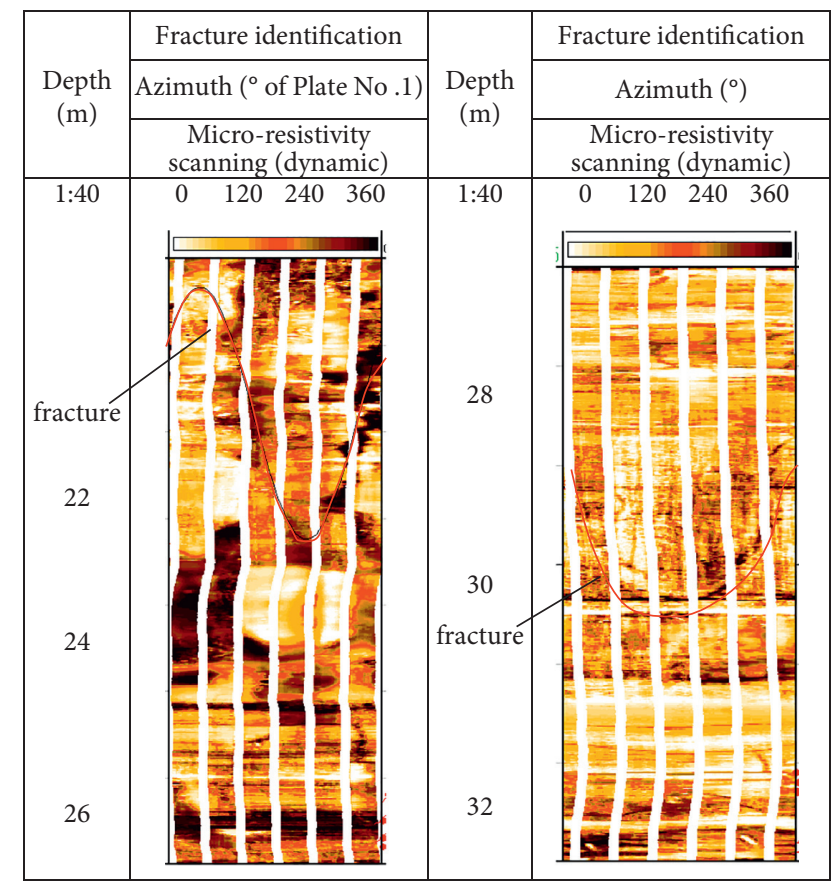

FIGURE 12: Microresistivity scanning imaging characteristic of drilling 8 .

development depth was calculated to be $7.28 \mathrm{~m}$, which is consistent with the results obtained by microresistivity scanning imaging technology.

\section{Comprehensive Research on the Height of Bedrock-Soil Composite Water-Flowing Fractured Zone}

6.1. Relationship between Water-Flowing Fractured Zone Specifics and Geotechnical Characteristics. We performed fitting of the difference between the height of the waterflowing fractured zone and the bedrock and soil thicknesses to examine the development of the water-flowing fractured zone horizon and degree, soil, or bedrock. The correlations between the parameters of the fractured zone and the geotechnical characteristics of the zone need to be analyzed. Therefore, the differences between the height of the waterflowing fracture and the bedrock and soil layer thicknesses were taken as variables to conduct the bivariate correlation 
TABLE 5: Comparison between the results obtained by microresistivity scanning imaging and simple hydrology observation of soil layer.

\begin{tabular}{|c|c|c|c|c|c|c|c|c|}
\hline \multirow{2}{*}{ Drilling } & \multicolumn{2}{|c|}{$\begin{array}{l}\text { Interpretation of } \\
\text { fractures by } \\
\text { microresistivity } \\
\text { scanning imaging }\end{array}$} & \multirow[b]{2}{*}{$\begin{array}{l}\text { Depth of } \\
\text { the } \\
\text { fractures } \\
(\mathrm{m})\end{array}$} & \multirow[b]{2}{*}{$\begin{array}{c}\text { Water } \\
\text { level } \\
\text { existence }\end{array}$} & \multirow[b]{2}{*}{$\begin{array}{c}\text { Rate of } \\
\text { water level } \\
\text { decline } \\
\left(\mathrm{m} \bullet \mathrm{min}^{-1}\right)\end{array}$} & \multirow[b]{2}{*}{$\begin{array}{l}\text { Drilling flushing } \\
\text { fluid consumption } \\
\text { per unit time }\left(\mathrm{L} \bullet \mathrm{s}^{-}\right. \\
\left.{ }_{1}^{1}\right)\end{array}$} & \multirow{2}{*}{ Comparative results } & \multirow{2}{*}{$\begin{array}{c}\text { Ratio of the } \\
\text { water-flowing } \\
\text { fractured zone } \\
\text { to the mining } \\
\text { height }\end{array}$} \\
\hline & $\begin{array}{l}\text { Depth of } \\
\text { the } \\
\text { fractures } \\
(\mathrm{m})\end{array}$ & $\begin{array}{l}\text { Fracture } \\
\text { numbers/ } \\
\text { article }\end{array}$ & & & & & & \\
\hline \multirow[b]{2}{*}{$\begin{array}{l}\text { Drilling } \\
8\end{array}$} & 21.8 & \multirow[b]{2}{*}{2} & 21.92 & No & - & 1.3 & $\begin{array}{l}\text { No water level; total } \\
\text { pump leakage. The rock }\end{array}$ & \multirow[b]{2}{*}{28.5} \\
\hline & 29.9 & & 29.12 & No & - & 1.3 & $\begin{array}{l}\text { mass is broken. Those } \\
\text { two methods confirm } \\
\text { each other better }\end{array}$ & \\
\hline \multirow{3}{*}{$\begin{array}{l}\text { Drilling } \\
9\end{array}$} & $7.8-7.9$ & & 7.79 & Yes & 0.026 & 0.6933 & $\begin{array}{l}\text { The water level declines } \\
\text { to zero and the rate of } \\
\text { decline suddenly }\end{array}$ & \multirow{3}{*}{28.3} \\
\hline & 18.4 & 4 & 16.67 & Yes & 0.380 & 0.7917 & $\begin{array}{l}\text { changes } \\
\text { No water level; total } \\
\text { pump leakage. Those }\end{array}$ & \\
\hline & 22.4 & & 22.97 & No & - & 2.0742 & $\begin{array}{l}\text { two methods confirm } \\
\text { each other better }\end{array}$ & \\
\hline
\end{tabular}

TABle 6: Types, characteristics, and depth range of the main fracture for drilling 8 .

\begin{tabular}{lcccc}
\hline $\begin{array}{l}\text { Geological } \\
\text { stratification }\end{array}$ & $\begin{array}{c}\text { Depth } \\
(\mathrm{m})\end{array}$ & $\begin{array}{c}\text { Inclination } \\
\left({ }^{\circ}\right)\end{array}$ & $\begin{array}{c}\text { Towards } \\
\left({ }^{\circ}\right)\end{array}$ & $\begin{array}{c}\text { Scope } \\
(\mathrm{m})\end{array}$ \\
\hline Soil & 21.8 & 85.8 & $143-323$ & $20.7-23.8$ \\
Bedrock & 29.9 & 57.3 & $68.6-249$ & $28.7-30.2$ \\
\hline
\end{tabular}

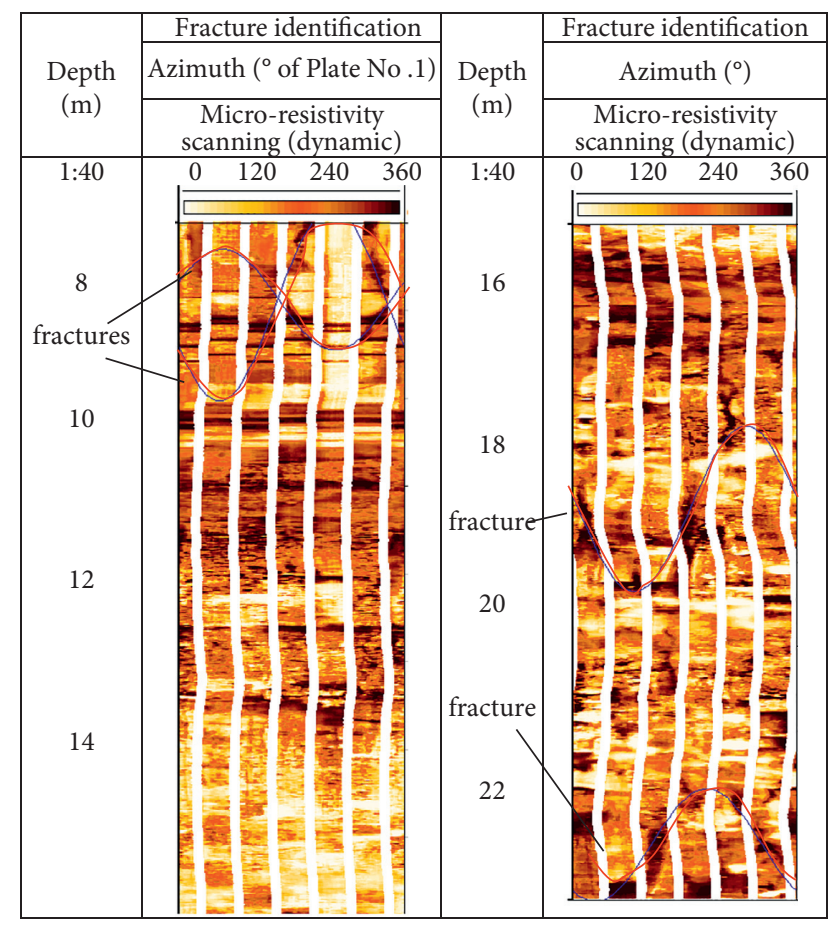

FIGURE 13: Microresistivity scanning imaging characteristic of drilling 9.
Table 7: Types, characteristics, and depth range of the main fracture for drilling 9 .

\begin{tabular}{lcccc}
\hline $\begin{array}{l}\text { Geological } \\
\text { stratification }\end{array}$ & Depth $(\mathrm{m})$ & Inclination $\left(^{\circ}\right)$ & Towards $\left({ }^{\circ}\right)$ & $\begin{array}{c}\text { Scope } \\
(\mathrm{m})\end{array}$ \\
\hline \multirow{4}{*}{ Soil } & 7.8 & 84.4 & $155-335$ & $7.5-9.0$ \\
& 7.9 & 84.4 & $155-335$ & $7.5-9.0$ \\
& 18.4 & 83.7 & $9.1-189.1$ & $17.5-19.2$ \\
& 22.4 & 80.8 & $126.1-306.1$ & $21.8-23.2$ \\
\hline
\end{tabular}

analysis. A significant correlation was present at the set significance level of 0.01 , indicating that the two groups of variables can be subjected to correlation analysis.

Time series analysis is a statistical method for dynamic data processing. This approach is based on the random process theory and mathematical statistics and is employed to study the statistical laws followed by random data sequences for solving practical problems. Classical statisticians assume that data sequences are independent, whereas time series analysis focuses on the interdependence of data sequences. In this paper, we subjected the two groups of data to the time series analysis method.

First of all, the soil layer data was processed; based on the change of the soil layer, $20 \mathrm{~m}$ was set as a section point. Then, the data group was divided into seven sections, forming seven groups of continuous time series data. The data in each group of time were not unique and were clustered to select a data group that was most representative of the region. Finally, seven groups of data were formed.

Second, the seven groups of data variables were analyzed by trend analysis (Figure 10) using the exponential smoothing method. We concluded that the difference between the height of the water-flowing fractured zone and the bedrock first increased and then leveled off before declining 
as the soil layer increases. The difference between the height of the water-flowing fractured zone and the bedrock increased within the thickness range of $0-20 \mathrm{~m}$ soil layer in the first sequence. In the range of $20-100 \mathrm{~m}$ soil layer thickness, namely, the second, third, fourth, and fifth section sequences, moderate differences were observed between the height of the water-flowing fractured zone and the bedrock. Logistic analysis showed that the inflection point of the group data appeared in the second section of the time series, namely, in the range of $20-40 \mathrm{~m}$ the soil layer thickness. In the soil layer thickness in the range of 100-140 m, specifically, in the sixth and seventh sequences, the difference between the height of the water-flowing fractured zone and the bedrock showed a downward trend.

Figure 14 can be divided into four blocks (I, II, III, and IV) by two lines: a horizontal line marking no height difference between the water-flowing fractured zone and the bedrock and a vertical line marking the soil thickness at $20 \mathrm{~m}$.

6.1.1. Thick Bedrock and Thick Soil Region (I). Only two isolated points existed in the region, which indicated that this situation in the study area is uncommon, and the development of the height of the water-flowing fractured zone was limited, not leading to the bedrock.

6.1.2. Thick Bedrock and Thin Soil Region (II). The bedrock in the region was thick, and the height of the water-flowing fractured zone increased rapidly with the elevation of the soil layer, indicating that the key layer had not been broken at that time point. The soil layer exerted a load, and a thicker soil layer led to a greater height of the water-flowing fractured zone.

6.1.3. Thin Bedrock and Thin Soil Region (III). The bedrock in the region was thin, and the water-flowing fracture height penetrated through the bedrock, while the key layer was broken. With the increase of the thickness of the soil layer, the height of the water-flowing fractured zone rose rapidly, which implied that the soil layer still exerted its load layer that accelerated the rise of the height of the water-flowing fractured zone. However, compared with region II, the rising rate decreased, showing that the soil layer had an inhibitory effect on the development of the height of the water-flowing fractured zone as compared with bedrock.

6.1.4. Thin Bedrock and Thick Soil Region (IV). The bedrock was thin in the region, and the height of the water-flowing fracture penetrated the bedrock, and the key layer was broken. The increase in the thickness of the soil layer basically did not change the height of the water-flowing fractured zone, which reveals that the rise in the height of the water-flowing fractured zone was suppressed by the soil layer. As can be seen from Figure 14, when the thickness of the soil layer was greater than $70 \mathrm{~m}$, the height of the water-

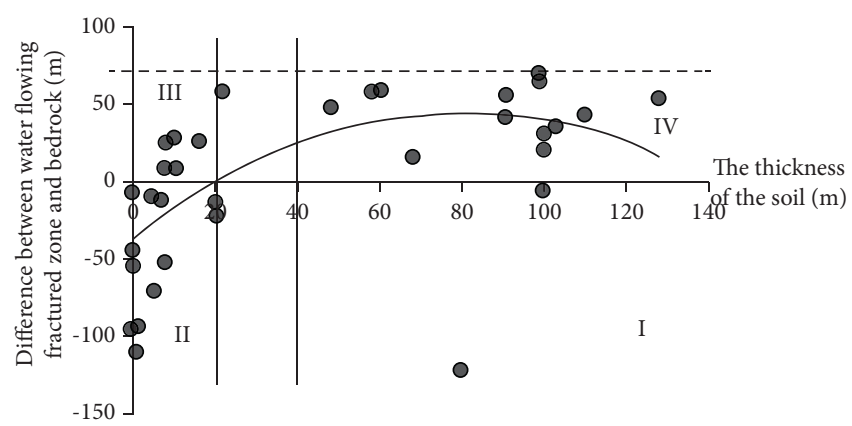

FIGURE 14: Relationship between the difference between fissure zone and bedrock thickness and soil thickness.

flowing fractured zone could not lead through the soil layer, indicating that when the thick soil layer exists, the height of the water-flowing fractured zone would not directly communicate with the overlying water on the soil layer. The fitting trend line shows that a $70 \mathrm{~m}$ soil layer was the boundary: the thickness of the soil layer at a depth lower than $70 \mathrm{~m}$ increased with the rise in the loess content, whereas the soil layer at a depth greater than $70 \mathrm{~m}$ decreased with the increase in the loess amount.

In summary, the development of the height of the waterflowing fractured zone was initially regulated by the thickness of the bedrock. When the bedrock was thick, the soil layer acted mainly as a load, whereas when the bedrock was thin, the soil layer exerted both load and inhibitory effect.

6.2. Study on the Relationship between the Height of the WaterFlowing Fractured Zone and Multifactor Fitting. In this paper, multiple regression analysis was used to predict the height of the water-flowing fractured zone. Regression analysis is a method applied to establish the mathematical relationship between statistical observations, which explains the change of dependent variables by the change of independent variables. It also predicts the possible value of dependent variables by the value of independent variables [24]. Multiple regression analysis is employed to establish a prediction model by analyzing the correlation between two or more independent variables and one dependent variable. A linear relationship between independent and dependent variables is called multiple linear regression analysis. Many nonlinear regressions can be solved by multiple linear regressions, and thus the linear regression method can be used to solve nonlinear regression prediction problems.

Multivariate linear regression analysis was utilized to analyze the correlation between $n$ independent variables and dependent variables. Its basic model is described by

$$
y=\beta_{0} x_{0}+\beta_{1} x_{1}+\beta_{2} x_{2}+\cdots+\beta_{n} x_{n}+u
$$

We used the least square method to calculate the regression coefficients $\beta_{1}, \beta_{2}, \ldots, \beta_{n}, \beta_{0}$, and the process is as follows: 


$$
f\left(x_{i}\right)=\sum\left(y_{i}-\widehat{y}_{1}\right)^{2}=\sum\left(y_{i}-\beta_{0}-\beta_{1} x_{1 i}-\beta_{2} x_{2 i}-\cdots-\beta_{n} x_{n i}\right)^{2}=\min ,
$$

where $x_{1 i}, x_{2 i}, \ldots, x_{n i}$ are independent variables and $y_{i}$ is dependent variables. The independent variables and the dependent variables are all specific known observed values. To find a pair of regression coefficients, the following formula is derived for $\beta_{0}, \beta_{1}, \beta_{2}, \ldots, \beta_{n}$, and its first derivative is 0 .

$$
\left\{\begin{array}{l}
L_{11} \beta_{1}+L_{12} \beta_{2}+\cdots+L_{1 n} \beta_{n}=L_{1 y}, \\
L_{21} \beta_{1}+L_{22} \beta_{2}+\cdots+L_{2 n} \beta_{n}=L_{2 y}, \\
\cdots \\
L_{n 1} \beta_{1}+L_{n 2} \beta_{2}+\cdots+L_{n n} \beta_{n}=L_{n y} .
\end{array}\right.
$$

Here,

$$
\begin{aligned}
& L_{i j}=L_{j i}=\sum\left(x_{i j}-\overline{x_{1}}\right)\left(x_{i j}-\overline{x_{j}}\right), \\
& L_{i y}=\sum\left(x_{i j}-\overline{x_{1}}\right)\left(y_{i}-\overline{y_{1}}\right) .
\end{aligned}
$$

Because $L_{i 1}, L_{i 2}, L_{i n}, \ldots, L_{\mathrm{i} y}(i=1,2, \ldots, n)$ are known values, that is, $x_{i j}, y_{i}, \overline{x_{1}}, \overline{y_{1}}(i=1,2, \ldots, n)$ are specific known observed values, $\beta_{1}, \beta_{2}, \ldots, \beta_{n}$ are $n$ unknown values and to solve $n$ equations. Therefore, $\beta_{1}, \beta_{2}, \ldots, \beta_{n}$ can be solved by determinant or elimination methods, and then $\beta_{0}$ can be obtained. When judging a close degree of the linear relation between variables in the regression equation, a quantitative index, correlation coefficient, is needed:

$$
R\left(R^{2}(y, 1,2, \ldots, n)=\frac{\sum\left(\widehat{y}_{1}-\bar{y}^{2}\right)}{\sum\left(y_{i}-\bar{y}^{2}\right)}\right) .
$$

A value of $R$ closer to 1 indicates that the so-called regression equation is more accurate.

The correlation between the height of the water-flowing fractured zone and various factors was assessed by SPSS. This software provides a simple statistical description to a complex multivariate statistical analysis. When analyzing the correlation between the height of the water-flowing fractured zone and the single-factor indexes, considering that other influencing factors were similar, representative data were selected to establish the multiple regression model with the largest correlation coefficient.

The multifactor fitting model is as follows:

$$
y=24.73 x_{1}+0.135 x_{2}+0.149 x_{3}+1.946
$$

where $y$ is the height of the water-flowing fractured zone, $x_{1}$ is the thickness of mining, $x_{2}$ is the thickness of soil, and $x_{3}$ is the difference between the height of the water-flowing fractured zone and the thickness of bedrock. Table 8 lists the proposed parameters and their values.

The following points can be seen from (7):

(i) The largest coefficient of mining thickness shows that the height of the water-flowing fractured zone in coal seam mining is affected mainly by the mining thickness; the larger the mining thickness is, the higher the height of the water-flowing fractured zone is. (ii) The contribution of the soil layer to the height of the water-flowing fractured zone is slightly smaller than that of the bedrock. Both increase with the rise in the bedrock and soil layer thicknesses, indicating that they mainly exert load action.

(iii) The constant term is smaller, indicating that the variation range of the height of the water-flowing fractured zone is larger, and different mining and geological conditions cause certain differences in the height of the water-flowing fractured zone.

In addition, the results of the single-factor analysis showed that different thicknesses of the bedrock and soil layer contributed to variations in the height of the waterflowing fractured zone. Therefore, multifactor fitting analysis was performed following the aforementioned zoning as follows.

(1) In area I, the geological conditions in the study area had a lower impact, with no statistical significance.

(2) In area II, when the soil layer was less than $20 \mathrm{~m}$, if the height of the water-flowing fractured zone did not penetrate the bedrock, the calculation formula is as follows:

$$
y=18.68 x_{1}+0.356 x_{2}+0.058 x_{3}+10.714,
$$

where $y$ is the height of the water-flowing fractured zone, $x_{1}$ is the thickness of coal seam mining, $x_{2}$ is the thickness of the soil layer, and $x_{3}$ is the thickness of bedrock. Table 9 lists the proposed parameters.

It can be seen from (8) that when the bedrock is thick, but the soil layer is thin, the following characteristics are evident:

(a) Mining thickness is still the main influencing factor. The larger the mining thickness is, the higher the height of the water-flowing fractured zone is.

(b) The contribution of the soil layer to the thickness of the bedrock is much greater, and the load action of the soil layer also plays a part.

(c) The constant term is larger, indicating that the variation range of the height of the water-flowing fractured zone is smaller, and all of them are greater than $10.714 \mathrm{~m}$.

(3) The following calculation formula is suggested for area III, where the height penetrates the bedrock to reach the soil layer, and the soil layer is less than $20 \mathrm{~m}$ :

$$
y=-6.654 x_{1}+2.99 x_{2}+1.378 x_{3}-12.357
$$

where $y$ is the height of water-flowing fractured zone, $x_{1}$ is the thickness of the coal seam mining, $x_{2}$ is the thickness of the soil layer, and $x_{3}$ is the thickness of 
TABle 8: Proposed parameters.

\begin{tabular}{lcccc}
\hline$R$ & $R^{2}$ & Standard estimate error & $F$ & D-W \\
\hline 0.915 & 0.837 & 12.486 & 54.97 & 1.39 \\
\hline
\end{tabular}

TABLE 9: Proposed parameters of the calculation formula for area II.

\begin{tabular}{lcccc}
\hline$R$ & $R^{2}$ & Standard estimate error & $F$ & D-W \\
\hline 0.949 & 0.901 & 9.97 & 24.3 & 2.13 \\
\hline
\end{tabular}

the bedrock. The proposed parameters are presented in Table 10.

It can be seen from (9) that when the bedrock is thin and the soil layer is thin, it has the following characteristics:

(a) The contribution of the mining thickness to the height of the water-flowing fractured zone is negative; that is, a larger mining thickness results in a smaller height of the water-flowing fractured zone. As visible from the original data of the corresponding area, the height of the waterflowing fractured zone in this region reached the surface. Thus, the observation value of the height of the water-flowing fractured zone is small. A larger mining thickness leads to a greater error of the height of the water-flowing fractured zone; that is, the observation values are mainly related to the buried depth, namely, the thicknesses of the bedrock and the soil layer.

(b) In this case, the contribution of the soil layer is larger than that of the bedrock, and both exerted a positive contribution.

The reason for this effect is that the height of the water-flowing fractured zone penetrated the surface. Greater thicknesses of the soil layer and the bedrock have resulted in a greater height of the water-flowing fractured zone.

(c) The constant term is negative, whereas $y$ is positive, which indicates that the range of the height of the water-flowing fractured zone is very large.

(4) The calculation formula for area IV, where the height of the water-flowing fractured zone penetrated the bedrock and reached the soil layer and the soil layer was greater than $40 \mathrm{~m}$, is as follows:

$$
y=32.7 x_{1}+0.292 x_{2}+0.428 x_{3}-78.995,
$$

where $y$ is the height of water-flowing fractured zone, $x_{1}$ is the thickness of coal seam mining, $x_{2}$ is the thickness of the soil layer, and $x_{3}$ is the thickness of the bedrock. Table 11 lists the suggested parameters. It can be seen from (10) that when the bedrock is thin and the soil layer is thick, the following characteristics are evident:
TABle 10: Proposed parameters of the calculation formula for area III.

\begin{tabular}{lcccc}
\hline$R$ & $R^{2}$ & Standard estimate error & $F$ & D-W \\
\hline 0.964 & 0.93 & 12.31 & 13.318 & 2.2 \\
\hline
\end{tabular}

TABLE 11: Proposed parameters of the calculation formula for area IV.

\begin{tabular}{lcccc}
\hline$R$ & $R^{2}$ & Standard estimate error & $F$ & D-W \\
\hline 0.968 & 0.937 & 8.67 & 54.45 & 1.459
\end{tabular}

(i) Most of the water-flowing fractured zone is developed by the soil layer, and most of them do not reach the surface, so the mining thickness contributes considerably to the height of the water-flowing fractured zone.

(ii) In this case, the soil layer exerts both load and an inhibitory effect, and thus its contribution rate is lower than that of the bedrock.

(iii) The constant term is negative, whereas $y$ is positive, which indicates that the range of the height of the water-flowing fractured zone is very large.

\section{Conclusion}

(1) Research on the height of the water-flowing fractured zone for water-retaining coal mining in the area is of great practical significance.

(2) For the first time, the microresistivity scanning imaging technology was applied to study the development law of the water-flowing fracture in the soil layer under the mining conditions in Zhangjiamao coal mine. The detection results are more accurate than those of the physical and numerical simulations, which can further expand the detection area and fully confirm the reliability of the detection results.

(3) The water-flowing fracture of the soil layer was found in this study, which lays a foundation for research on the development law of water-flowing fractures in soil layers.

(4) The development height of the bedrock-soil waterflowing fractured zone was systematically studied, and a mathematical model for its prediction with different bedrock and soil thicknesses was established, which provided a theoretical basis for determining the development height of the waterflowing fractured zone.

\section{Data Availability}

There are eleven tables providing the data used to support this study. All these data were obtained from geological prospecting, field test, laboratory test, indoor test, and mathematical calculations and any details about them are indicated in this paper. The exploration, experimental, and 
original data used to support the findings of this study are included within this article. No additional data are available.

\section{Conflicts of Interest}

The authors declare that there are no conflicts of interest.

\section{Acknowledgments}

The authors would like to express gratitude to the National Basic Research Program of China (2014CB047103) and the National Natural Science Foundation of China (41472234) for supporting this work.

\section{References}

[1] S. M. Wang, Q. X. Huang, L. M. Fan, Z. Y. Yang, and T. Shen, "Study on overburden aquclude and water protection mining regionazation in the ecological fragile mining area," Journal of China Coal Society, vol. 35, no. 1, pp. 7-14, 2010.

[2] L. M. Fan and G. Z. Wang, "The influence and protection of Coal Mining for Salawusu groundwater," Mining Technology, vol. 6, no. 3, pp. 422-428, 2006.

[3] S. N. Dong, Y. D. Ji, H. Wang, B. F. Zhao, and H. D. Cao, "Prevention and control technology and application of roof water disaster in Jurassic coal field of Ordos Basin," Journal of China Coal Society, vol. 45, no. 7, pp. 2367-2375, 2020.

[4] M. G. Qian, X. X. Miao, and J. L. Xu, Critical Layer Theory of Rock Layer Control, China University of Mining Press, Xuzhou, China, 2003.

[5] J. L. Xu, W. B. Zhu, and X. Z. Wang, "New method to predict the height of fractured water-conducting zone by location of key strata," Journal of China Coal Society, vol. 37, no. 5, pp. 762-769, 2012.

[6] State Bureau of Coal Industry, Construction, Water Body, Railway and Main Roadway Coal Pillar Retention and Coal Pressure Mining Rules, Coal Industry Press, Beijing, China, 2000.

[7] L. M. Bai, S. X. Yin, and W. Li, "Calculation formula of water conducting zone height in roof for fully mechanized mining and its adaptability analysis," Coal Geology \& Exploration, vol. 41, no. 5, pp. 36-39, 2013.

[8] S. X. Yin, B. Xu, H. Xu, and X. X. Xia, "Study on height calculation of water conducted fractured zone caused by fully mechanized mining," Coal Science and Technology, vol. 41, no. 9, pp. 138-142, 2013.

[9] S. M. Wang, Q. X. Huang, L. M. Fan, and W. K. Wang, Study on Coal Development and Ecological Water Level Protection in Ecologically Fragile Areas, science Press, "Beijing, 2010.

[10] B. C. Zhao, Z. R. Liu, C. Tong, and C. L. Wang, "Relation between height of water flowing fractured zone and mining parameters," Journal of Mining and Safety Engineering, vol. 32, no. 4, pp. 634-638, 2015.

[11] B. C. Zhao, S. Y. Wang, J. B. Liu et al., "Height of water flowing fractured zone in Yuyang mining area," Journal of Xi'an University of Science and Technology, vol. 36, no. 3, pp. 343-348, 2016.

[12] W. S. Li, W. Li, and S. X. Yin, "Study on development height of water flow crack zone in roof above fully mechanized one passing full seam mining face," Coal Science and Technology, vol. 40, no. 6, pp. 104-107, 2012.

[13] D. M. Yang, W. B. Guo, G. B. Zhao, Y. Tan, and W. Q. Yang, "Height of water-conducting zone in longwall top-coal caving mining under thick alluvium and soft overburden," Journal of China Coal Society, vol. 44, no. 11, pp. 3308-3316, 2019.

[14] J. L. Yang and Y. H. Teng, "Study on development law of water conducted fracture zone in top coal of fully mechanized top coal caving mining face," Coal Science and Technology, vol. 37, no. 12, pp. 100-102, 2009.

[15] Q. X. Huang, B. N. Wei, and W. Z. Zhang, "Study of down ward crack closing of clay aquiclude in shallowly buried coal seam," Journal of Mining and Safety Engineering, vol. 27, no. 1, pp. 35-39, 2010.

[16] Y. P. He, Q. X. Huang, B. Q. Wang, Y. P. Miao, and J. Li, "Field-measurement study on roof breaking angle of working face with large mining height in shallow coal seam," Journal of Mining and Safety Engineering, vol. 36, no. 4, pp. 746-752, 2019.

[17] Q. X. Huang, J. W. Du, E. K. Hou, and F. Yang, "Research on overburden and ground surface cracks distribution and formation mechanism in shallow coal seams group mining," Journal of Mining and Safety Engineering, vol. 36, no. 1, pp. 7-15, 2019.

[18] Z. G. Cao, J. M. Zhang, H. Wang, G. J. Zhang, and W. Z. Zhang, "Physical modelling and scenario simulation of coal \& water co-mining in coal mining areas in western China," Journal of China Coal Society, vol. 46, no. 2, pp. 638-651, 2021.

[19] H. J. Wang, F. X. Jiang, Y. H. Cheng, R. J. Si, and Q. Yue, "Study on the height of water flowing fractured zone by micro-seismic monitoring," Coal Engineering, vol. 38, no. 3, pp. 74-76, 2006.

[20] E. K. Hou, J. C. Fan, X. S. Xie et al., "Development characteristics of water-conducting fractured zone in deep coal seam based on microseismic monitoring," Coal Geology \& Exploration, vol. 48, no. 5, pp. 89-96, 2020.

[21] T. Li, H. Feng, S. J. Wang, and T. Chen, "Study on micro resistivity scan imaging logging applied to detect water flow cracks of mining soil layer," Coal Science and Technology, vol. 44, no. 8, pp. 52-55, 2016.

[22] J. Feng, S. J. Wang, T. Chen, E. K. Hou, and T. Li, "Height of water flowing fractured zone of soil layer in ecologically fragile mining area," Coal Geology \& Exploration, vol. 46, no. 1, pp. 97-100, 2018.

[23] N. Guo, "Application of micro resistivity scanning imaging logging in fracture identification," China Equipment, vol. 69, no. S1, p. 61, 2014.

[24] X. Q. He and W. Q. Liu, Applied Regression Analysis, People's University of China Press, Beijing, China, 2001. 